\title{
DEVELOPMENT OF ONLINE COURSE SATISFACTION SCALE
}

\author{
Dr. Fatma BAYRAK \\ ORCID: 0000-0001-8500-1456 \\ Faculty of Education \\ Hacettepe University \\ Ankara, TURKEY \\ Dr. Moanes H. TIBI \\ ORCID: 0000-0002-0661-5212 \\ Faculty of Education \\ Beit Berl College \\ Kfar Saba, ISRAEL \\ Dr. Arif ALTUN \\ ORCID: 0000-0003-4060-6157 \\ Faculty of Education \\ Hacettepe University \\ Ankara, TURKEY
}

Received: 25/11/2019 Accepted: 10/02/2020

\begin{abstract}
Higher education institutions consider student satisfaction to be one of the main factors in determining the quality of their online learning. The purpose of this study was to develop a reliable, valid, and practical instrument to measure online students' satisfaction as well as to explore the psychometric and theoretical concerns surrounding the construct validity of existing satisfaction scales. The study was carried out in 2017-2018 fall and spring with participants consisting of freshmen who took the online course in a state university $\left(\mathrm{N}_{\text {fall }}=1585 ; \mathrm{N}_{\text {spring }}=1206\right.$ ). In this study exploratory factor analysis (EFA) (Study 1- $\mathrm{N}_{\mathrm{EFA}}=921$ ) and confirmatory factor analysis (CFA) (Study $1-\mathrm{N}_{\mathrm{CFA}}=664$; Study $1-\mathrm{N}_{\mathrm{CFA}}=1206$ ) were performed to assess the construct validity of the scale's measures. As proof of validity, the effect of gender on satisfaction was examined, for which independent sample t-test was performed. For the criterion validity, the relationship between computer and internet self-efficacy and satisfaction scores of the learners was examined. The finalized version of satisfaction scale, consisting of eight items, demonstrated that the scale is suitable for general use. Suggestions for future researchers and practioners are proposed.
\end{abstract}

Keywords: Online learning, student satisfaction, scale development.

\section{INTRODUCTION}

Online learning has grown dramatically during the last decade in most parts of the world. Different reasons account for the increasing growth of online courses and programs. Green (2010) stated that universities and colleges are willing to develop and grow their online learning programs because they can attract more students at a lower cost. In addition, the students themselves are asking for more online courses since they claimed they save money and time when they do not drive to campus, and they are still able to maintain their work schedule while completing their educational goals (Green, 2010). For university and college leaders, student demand is the number one reason for increasing online offerings (Green, 2010). It is also to be stated that the continuous development of information and communication technologies helps in making the online teaching and learning experience smoother.

Despite the popularity of online learning, student satisfaction with online learning remains one of the most important indicators of the quality of online learning experiences (Ilgaz ve Gulbahar, 2015; Yukselturk \& 
Yildirim, 2008) and for higher education institutions one of the major elements in determining the quality of their online learning programs (Parahoo, Santally, Rajabalee \& Harvey, 2016). Student satisfaction with online learning can be related to several factors like online interactions (i.e. student-student, studentinstructor, student-content), course quality, assessment, computer/internet self-efficacy, perceived learning and student learning can be affected by student satisfaction with the learning experience (Harsasi \& Sutawijaya, 2018; Kirtman, 2009; Turhangil Erenler, 2019; Uusiautti, Maatta \& Leskisenoja, 2017; Young \& Norgard, 2006). When students are satisfied with their experience of online learning this will determine if they more likely will continue to enroll in other online courses. Knowledge of the factors that influence student satisfaction with online learning can help improve such online courses (Kaufmann, 2015; Kurucay \& Inan, 2017; Martin-Rodriguez, Fernandez-Molina, Montero-Alonso \& Gonzalez-Gomez, 2015). It is therefore important for faculty members involved in designing, developing and delivering online courses to seek the opinions and perceptions of online students about their successful learning experiences and share this information to advance the knowledge related to online learning.

Researchers have identified several factors that promote student satisfaction and motivation in online learning which include academic challenge and supportive learning activities (An, Kim \& Kim, 2008; Chen, 2014; Lister, 2014; Tibi, 2015); timely and explanatory feedback (Britto \& Rush, 2013; Sebastianelli, Swift \& Tamimi, 2015; Wallace, 2003); regular interaction with the instructor (Lister, 2014; Roper, 2007; Uusiautti et al., 2017); and positive interactions with peers (Kurucay \& Inan, 2017; Liaw \& Huang, 2013; Lister, 2014; Wallace, 2003). Gil (2008) found that administration, functionality, instruction, and interaction are the most four categories that affected online learning satisfaction. Among those categories, instruction and interaction were found to be the most important factors that have impacts on satisfaction with online learning.

Ralston-Berg, Buckenmeyer, Barczyk and Hixon (2015) investigated student perceptions of online course quality. The study included about 3000 participants taking an online college-level course. The results showed that participants rated clear instructions for getting started and ease of navigation at a high level. Also clearly stated assignment and grading policy were found to be important as one of the specific criteria for student expectations (Ralston-Berg et. al., 2015). Fedynich, Bradley and Bradley (2015) surveyed 249 graduate students to identify positive components that led to their satisfaction in online courses. The results indicated that interaction among students, interaction between the students and the instructor, and the instructor's role has a major impact on student satisfaction (Fedynich, el al., 2015). On the other hand, lowest levels of satisfaction by the research participants was found related to explanatory feedback given by the instructor, the wide range of content provided by the course, and the ample opportunities to interact with one another (Fedynich, el al., 2015). In addition, Jaggars and Xu (2016) investigated the impact of online course design on Student end-of-semester performance in 23 online courses at two community colleges. The results of their research indicated that quality of interpersonal interaction within the online courses relates positively and significantly to student grades. They also found that frequent and effective learner-instructor interaction creates an online learning environment that encourages students to commit themselves to the course and perform at a stronger academic level. Eom and Ashill (2016) investigated 372 responses from students who have completed at least one online course at a university in the United States according to critical success factors that influence quality of online learning. They concluded that instructor-student dialogue, student-student dialogue, and course design significantly affect students' satisfaction and learning outcomes. Research also indicated that perceived usefulness, perceived ease of use and compatibility of the online learning environment improves user's satisfaction of the information system (Chiu, Hsu, Sun, Lin \& Sun, 2005; Rios, Elliott \& Mandernach, 2018). Sahin and Shelly (2008) stated that student perceptions and needs should be considered central in designing, developing, and delivering online courses.

Research on students' perceptions of online learning quality (Milheim, 2012; Ward, et al., 2010; Young \& Norgard, 2006) emphasize that the key factors that affect students satisfaction with online learning are: interactivity (e.g., Croxton, 2014; instructor variables (e.g., Fedynich et al., 2015; Martin-Rodriguez et al., 2015), course design and content (e.g., Jaggars \& Xu, 2016; Lister, 2014; Ralston-Berg et. al., 2015), and technical issues of the online learning environment (e.g., Bolliger, 2004). So far, most research was done with off site learners and/or blended learning students. Yet, which factors would emerge or whether the previous constructs could be replicable in on-site and fully online learning experiences is scare. Therefore, the current 
study is, first, designed to develop a fully online (with synchronous and asynchronous modules) on-campus e-learning satisfaction questionnaire; secondly, it was aimed to report validity and reliability scores of the developed questionnaire.

\section{METHODOLOGY}

\section{Research Participants}

Starting from 2016-2017, a state university at Central Anatolia has started providing online courses to undergraduate students with Turkish Language I and II. These courses were offered by 57 faculty through a learning management system with both synchronous and asynchronous features. These courses were coordinated by 57 departments from various colleges and the Distance Education Research and Application Center. Each department supported the program with their teaching staff and the Center had the role of guiding the process, administering the process, and training the teaching staff for online learning.

The study was carried out in 2017-2018 fall and spring with participants consisting of freshmen who took the online course in a state university. After the completion of the 14-week course in the 2017-2018 Fall and 2017-2018 Spring terms, the scale was distributed to the students via e-mail trough the learning management system. The demographic information of the students who participated in the study is presented in the Table 1 and Table 2. The majority of students who answered the questionnaire (2017-2018 Fall 79\%; 2017-2018 Spring $86 \%$ ) had no previous experience of taking an online course (Table 2).

Table 1. Participants and Performed Statistical Procedures

\begin{tabular}{ccccc}
\hline Course & Study & Term & Study Groups & $\begin{array}{c}\text { Performed Statistical } \\
\text { Procedures }\end{array}$ \\
\hline Turkish Language I & Study I & 2017-2018 Fall & $\mathrm{N}_{\text {total }}=1585$ & EFA \\
& & $\mathrm{N}_{\text {EFA }}=921$ & $\mathrm{~N}_{\text {CFA }}=664$ & CFA \\
\hline Turkish Language II & Study II & 2017-2018 Spring & $\mathrm{N}=1206$ & CFA \\
\hline
\end{tabular}

Table 2. Participants according to gender and pre-online course experience

\begin{tabular}{cccc}
\hline & $2017-2018$ Fall (EFA) & 2017-2018 Fall (CFA) & 2017-2018 Spring \\
\hline Gender & $N_{\text {Female }}=617$ & $N_{\text {Female }}=428$ & $N_{\text {Female }}=827$ \\
& $N_{\text {Male }}=304$ & $N_{\text {Male }}==236$ & $N_{\text {Male }}=279$ \\
\hline $\begin{array}{c}\text { Has taken an online course } \\
\text { before }\end{array}$ & $N_{\text {Yese }}=203$ & $N_{\text {Yes }}=135$ & $N_{\text {Yes }}=170$ \\
& $N_{\text {No }}=718$ & $N_{\text {No }}=529$ & $N_{\text {No }}=1036$ \\
\hline
\end{tabular}

\section{Research Instruments}

Two instruments were utilized in order to measure undergraduate students' satisfaction with their online learning experiences. In the following section, these instruments are described in detail.

\section{Online Course Student Satisfaction}

The literature was searched and the data collection tools (Alshare, Freeze, Lane and Wen, 2011; Arbaugh, 2000; Bolliger and Halupa, 2012; Eryilmaz, 2012; Gecer and Topal, 2015; Gunawardena, LinderVanBerschot, LaPointe and Rao, 2010; Gunawardena and Zittle; 1997; Ilgaz, 2008). Prepared to measure the satisfaction structure were examined and a pool of 10 items was formed (Appendix 1). The items are rated in a 5-point Likert type, between 1 - strongly disagree and 5 - strongly agree. Six experts were reached to determine the scope validity of the substances created. Kappa statistics were calculated for each item since 
it was suggested to examine the kappa statistics when a small number of experts were reached within the scope validity (Yurdugul and Bayrak, 2012). After determining the Kappa statistics (Fleiss, 1981), it was decided to remove two items (item 5, item8). Both items (item 2, item 10) were found to be inadequate by some of the experts and it was determined that the kappa value was at the limit. Therefore, it was decided to examine the factor loadings of the two items as a result of factor analyzes and the data collection tool was finalized with eight items. The validity and reliability studies of the scale were reported in detail in the title of the findings.

\section{Computer/Internet Self-efficacy}

When the studies on satisfaction structure are examined, it is determined that there is a relationship between satisfaction and computer and/or internet self-efficacy (Kirmizi, 2015; Kuo, Walker, Belland, \& Schroder, 2013; Kuo, Walker, Schroder, \& Belland, 2014; Lim, 2001). Therefore, it was decided that there is a need to look at the relationship between computer and internet self-efficacy and satisfaction scores of the learners for the criterion validity. The adaptation of Online Learning Readiness Scale (Hung, Chou, Chen and Own, 2010) into Turkish was conducted by Yurdugul and Alsancak Sirakaya (2013). For this structure, Cronbach's alpha coefficient was reported as 0.92 and in this study it was calculated as 0.855 .

\section{FINDINGS}

\section{Study I}

Before conducting analyses, data were cleared and skewness values were examined and it was checked whether normality assumption was met. In order to examine the construct validity of the scale, an exploratory factor analysis was conducted with 921 observations randomly chosen in the 2017-2018 Fall term. Maximum likelihood (ML) extraction method was used in exploratory factor analysis. Then, confirmatory factor analysis was performed with the rest of the data $(n=664)$ in order to test its structure determined by Exploratory Factor Analysis. The results of exploratory and confirmatory factor analysis were reported below.

In 2017-2018 Fall term, a random part of the data was chosen and factor analysis was performed with 921 observations. The KMO value was 0.924 and the Barlett test was significant $(\mathrm{p}<0.05)$. Principal component analysis was utilized and it was determined that the extraction values of factors were between 0.501 and 0.786 at acceptable value ranges.

When deciding the number of factors in a questionnaire, Kaiser's criteria, the Scree test and parallel analysis methods were usually utilized (Williams, Onsman, Brown, 2010). Single factor (5.604) was found to be greater than 1 according to Kaiser's criteria. According to the Scree test, the break is observed after one (1) factor. It was also observed that a single factor existed according to parallel analysis (Patil, Singh, Mishra $\&$ Donavan, 2017). Based on these results, the OCSS consists of eight items in a single factorial structure, which explained $70,051 \%$ of the total variance. The reliability of the scale was tested using both the construct validity (0.949) and the Cronbach Alpha (0.938). Both values were above 0.70 and found to be valid as reported by Nunnully and Berstein (1994). AVE value was calculated as 0.701 (See, Table 3.).

Convergent validity was also examined since the scale was unidimensional in the context of construct validity. For convergent validity, it was determined whether factor loads and average variance extracted (AVE) values were greater than 0.50 . As shown in Table 3 , it was observed that the standardized factor loads of the scale items ranged between 0.708 and 0.887 . In addition, the average variance extracted (AVE) values were found to be greater than 0.50 (Fornell \& Larcker, 1981). Based on the findings, one-dimensional scale scores can be said to be valid and reliable.

The CFA was run on the other randomly determined portion of the data gathered in 2017-2018 Fall period. Once the data was cleared, confirmatory factor analysis was performed with 664 observations. The KMO value was 0.929 and the Barlett test was significant $(\mathrm{p}<0.05)$. For the confirmatory factor analysis, the recommended number of samples should be 5 or 10 times the number of items (Kline, 2005). Since the number of observations was 664 , this proposal was met. In the confirmatory factor analysis, error and fit indexes and proposed modifications were examined. The error and fit indices were found to be appropriate 
according to the expected criteria $\left(\mathrm{X}^{2}{ }_{(32)}=51.964, \mathrm{RMSEA}=0.056, \mathrm{GFI}=0.981 ; \mathrm{CFI}=0.993\right.$; $\mathrm{NNFI}=$ 0.988). Accordingly Hu and Bentler $(1995,1999)$, the fit index values above 0.90 and RMSEA value 0.06 below are considered acceptable.

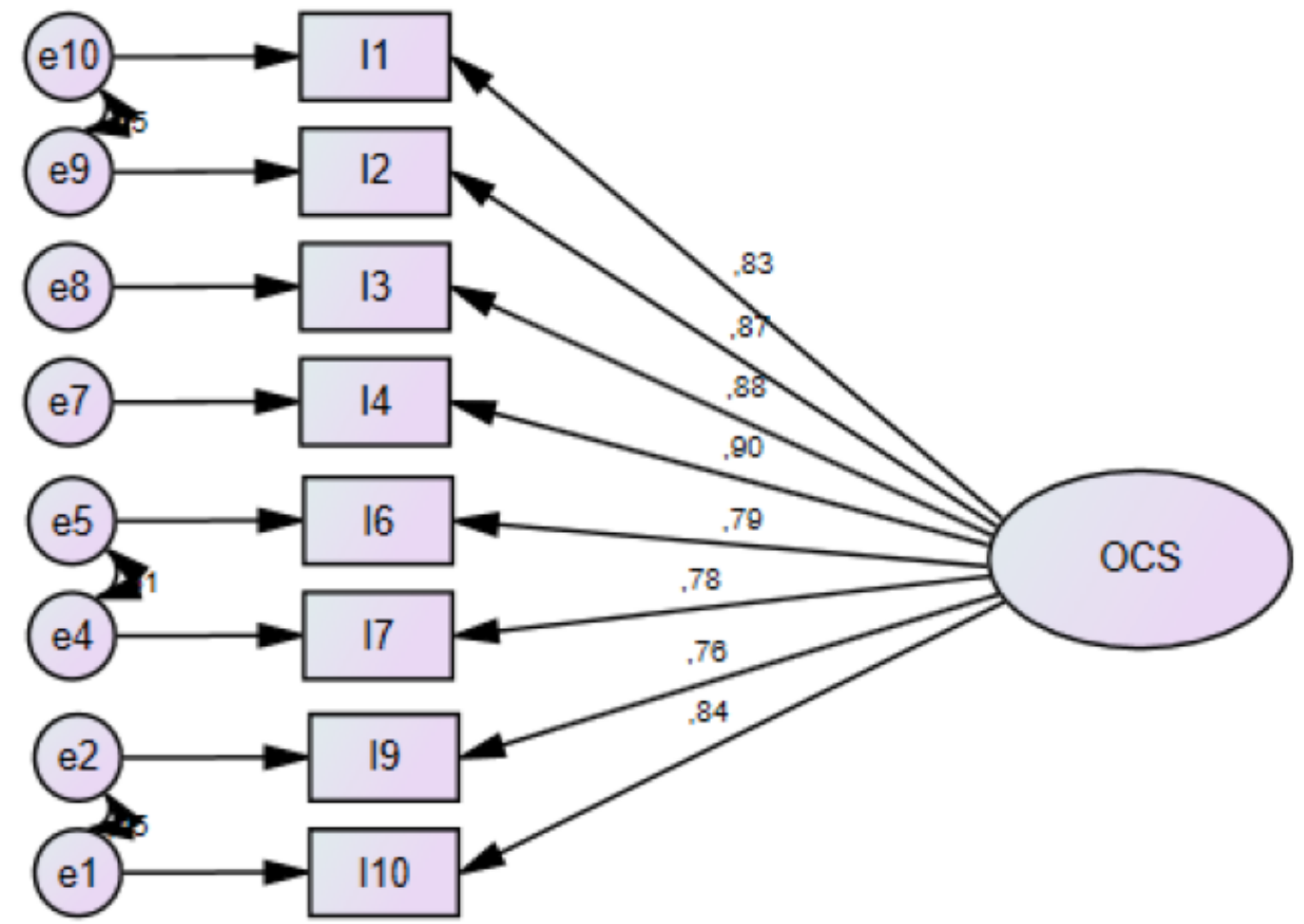

Figure 1. Satisfaction Scale (Standardized Factor Loadings)

The standardized factor loads of the scale items ranged between $0.78-0.90$ and the $t$ values for these factor loads were significant. In addition, the average variance extracted (AVE) values were found to be greater than 0.50 (Fornell \& Larcker, 1981; Hair, Black, Babin, \& Anderson, 2009). These values can be taken as evidence of convergent validity for the scale.

To determine the reliability of the scale, both construct reliability and Cronbach's alpha coefficient were calculated (Table 3). Both reliability levels were found to be greater than 0.70 for each dimension (Nunnully and Bernstein, 1994), confirming that the scale had a uni-dimensional structure.

\section{Study II}

To examine the construct validity of the scale, another confirmatory factor analysis was performed on the data collected in the 2017-2018 Spring term. After clearing the data, confirmatory factor analysis was performed with 1206 observations. The KMO value was 0.932 and the Barlett test was significant $(\mathrm{p}<0.05)$. Based on these values, it was found that the data could be factorized and the recommended number of samples was also met $(\mathrm{n}=1206)$. As a result of the analysis, it was determined that the error and fit indices were also appropriate according to the expected criteria $\left(\mathrm{X}^{2}(17)=61.272\right.$, RMSEA $=0.046$, GFI $=0.988$; $\mathrm{CFI}=$ 0.995; NNFI $=0.992$ ). 


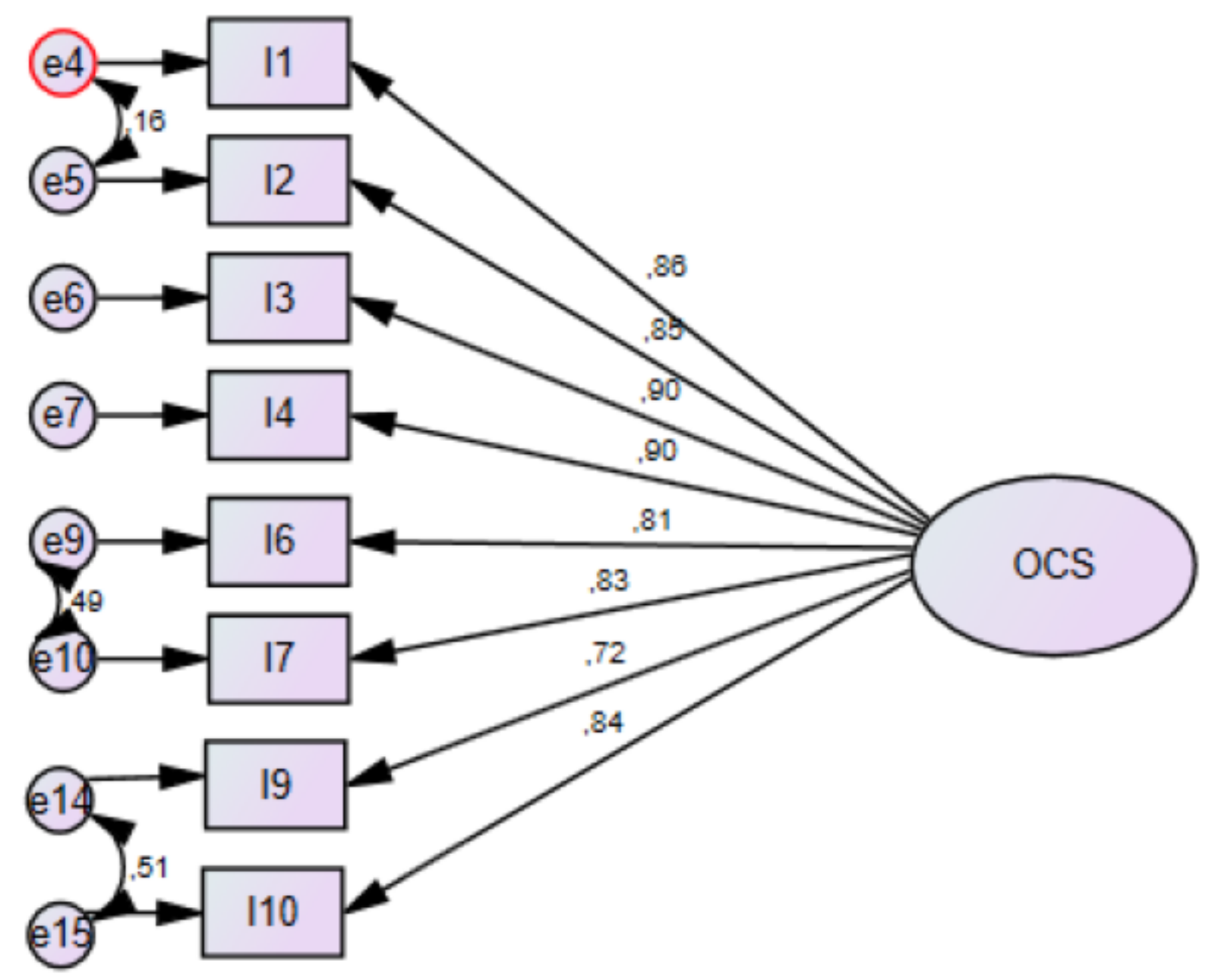

Figure 2. Satisfaction Scale (Standardized Factor Loadings)

The standardized factor loadings of the scale items ranged from 0.72 to 0.90 . In addition, it was determined that the average variance extracted (AVE) values were greater than 0.50 . These values can be seen as evidence of convergent validity for the scale. Both structural reliability and Cronbach's alpha coefficient were found to be greater than 0.70 (Table 3) (Nunnully and Bernstein, 1994). Based on these findings, it was confirmed that the scale was unidimensional, valid and reliable. 


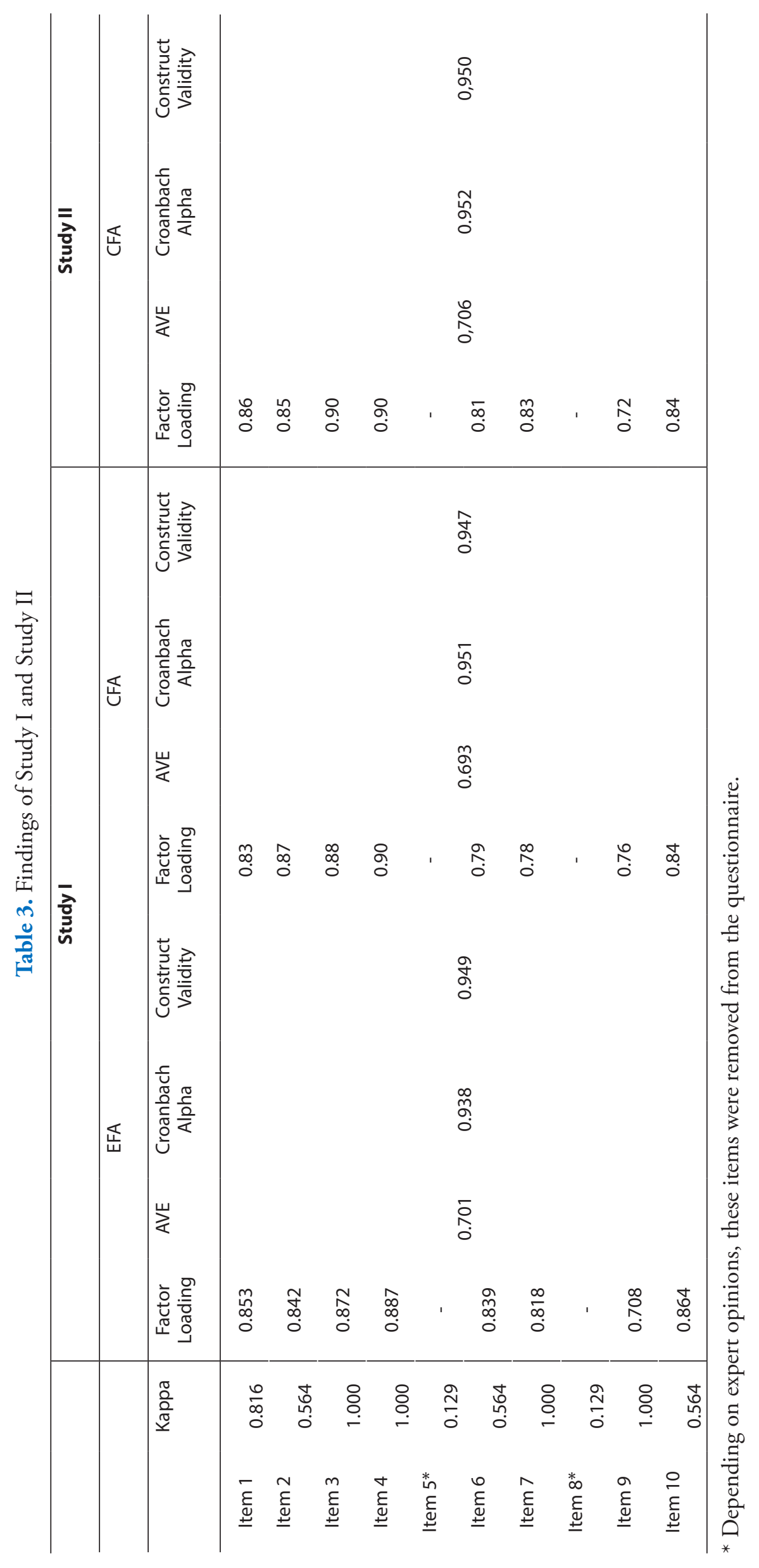


It is important to elaborate the test with a number of methods based on evidence collection (Kelecioglu \& Sahin, 2014). In this process, it is suggested to examine the group differences and their relationships with different structures along with factor analysis (Cronbach, \& Meehl, 1955). From this point of view, although it is stated that gender has an effect on the satisfaction structure and there is a difference in favor of women (Gonzalez-Gomez, Guardiola, Rodriguez, \& Alonso, 2012); it is expressed that gender does not have an effect on satisfaction in individuals who grew up in the millennium age (Harvey, Parahoo, \& Santall, 2017). Therefore, the gender variable was examined for group comparison and independent sample t-test was performed. As a result of the analysis (Table 4) there was no statistically significant difference observed between the groups $(\mathrm{p}>0.05)$. It can be said that this is evidence for the validity of test scores.

Table 4. The independent sample t-test to show gender differences in satisfaction.

\begin{tabular}{ccccccc}
\hline & $\mathrm{N}$ & Mean & SD & $\mathrm{df}$ & $\mathrm{t}$ & $\mathrm{p}$ \\
\hline Female & 827 & 29.157 & 7.679 & 1204 & -1.283 & 0.200 \\
Male & 379 & 29.791 & 8.578 & & & \\
\hline
\end{tabular}

For the criterion validity, the relationship between computer and internet self-efficacy and satisfaction scores of the learners was also examined. After examining the normality assumption, Pearson correlation coefficient was calculated. Descriptive analysis results are shown in Table 5. It was determined that there was a statistically significant relationship between computer and internet self-efficacy and satisfaction scores of students $(\mathrm{r}=0.302, \mathrm{p}<0.05$, Table 6$)$. This finding is evidence for the validity of the developed scale.

Table 5. Descriptive statistics between satisfaction and Computer/Internet Self-Efficacy Scores

\begin{tabular}{cccccccc}
\hline & $\mathrm{N}$ & Min Score & Max Score & $\overline{\mathrm{x}}$ & SD & Skewness & $\begin{array}{c}\text { Skewness } \\
\text { Standard Error }\end{array}$ \\
\hline Satisfaction & 1206 & 8 & 40 & 29.357 & 7.975 & -.926 & .070 \\
\hline $\begin{array}{c}\text { Computer / } \\
\text { Internet Self } \\
\text { Efficacy }\end{array}$ & 1179 & 3 & 15 & 11.137 & 2,705 & -.812 & .071 \\
\hline
\end{tabular}

Table 6. Correlation Matrix between satisfaction and Computer/Internet Self-Efficacy Scores

\begin{tabular}{ccc}
\hline & & Satisfaction \\
\hline Computer /Internet Self Efficacy & Pearson Correlation &, $302^{* *}$ \\
& $\mathrm{p}$ & .000 \\
& $\mathrm{~N}$ & 1179 \\
\hline
\end{tabular}

\section{CONCLUSIONS AND IMPLICATIONS}

On-site online experiences are valuable learning experiences for undergraduate students to live through the online learning experiences which would definitely be a part of their professional learning journey; increase their exposure to learning materials regardless of time and space; and, to provide learning materials in various medium to address learners' variability. Thus, we need valid, reliable, and easy-to-administer instruments to report back about how online learning is experienced by undergraduate students. Furthermore higher education institutions consider student satisfaction to be one of the main factors in determining the quality of their online learning (Dziuban, et. Al, 2015; McGorry, 2003).

The purpose of this study was to develop a reliable, valid, and practical instrument to measure online students' satisfaction. The research consists of two studies. In study I, an exploratory factor analysis was conducted with 921 observations randomly chosen in the 2017-2018 Fall term. Then, confirmatory factor analysis was performed with the rest of the data $(n=664)$ in order to test its structure determined by Exploratory Factor Analysis. Based on the findings, one-dimensional scale scores can be said to be valid and reliable. To examine the construct validity of the scale, another confirmatory factor analysis was performed on the data 
$(\mathrm{n}=1206)$ collected in the 2017-2018 Spring term. Based on the findings, it was confirmed that the scale was unidimensional, valid and reliable. The finalized version of satisfaction scale, consisting of eight items, demonstrated that the scale is suitable for general use.

After the factor analysis, different evidences for construct validity were collected. First, the effect of gender on satisfaction was examined. As a result of the analysis, there was no statistically significant difference observed between the groups. The reason for this can be said that the students currently studying at the university are millennium age students. Harvey, Parahoo, and Santall (2017) also reached this conclusion in their research. Secondly, the relationship between computer and internet self-efficacy and satisfaction was examined and a medium level relationship was found. Alqurashi (2016) found a similar result in her literature review. Based on these conclusions, this scale can be used both as a quality indicator in higher education institutions for online learning and to examine undergraduate students' perception of satisfaction in online and blended learning programs.

\section{BIODATA and CONTACT ADDRESSES of AUTHORS}

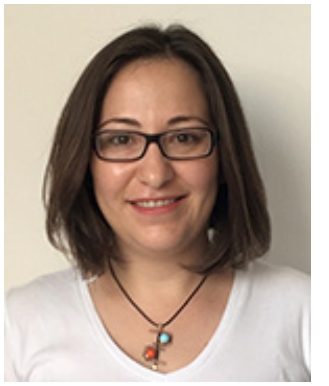

Dr. Fatma BAYRAK is an assistant professor at Computer Education and Instructional Technologies, Hacettepe University. Dr. Bayrak gained her Ph.D. in Computer Education and Instructional Technologies at July, 2014. Her academic interest areas are e-learning, assessment in online learning, technology enhanced assessment, feedback and reflective thinking. In addition to the lectures she has given, she has been a researcher in national and international projects. Over the years, she has written various articles and book chapters, participated in national and international conferences.

\section{Fatma BAYRAK}

Hacettepe University, Faculty of Education

Department of Computer Education and Instructional Technologies

Address: Hacettepe University, 06800, Ankara, Turkey

Phone: +90 3122977176

E-mail: fbayrak@hacettepe.edu.tr

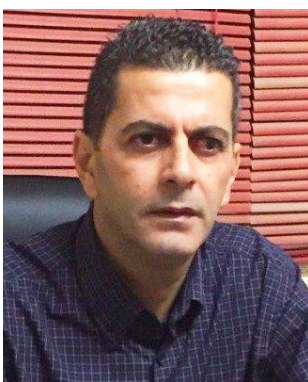

Dr. Moanes H. TIBI holds Bachelor's and Master's degrees in Computer Science from the Rheinische Friedrich-Wilhelms-Universitat Bonn in Germany. He earned his Ph.D. from Bar-Ilan University. Dr. Tibi has been lecturing in this field since 1995 and has served as the head of the Computer Science Department at Beit Berl Academic College between 2012-2016. Over the years, he has written various articles and books, participated in national and international Conferences. His principal fields of research and interest include developing teaching and learning models in online environments, and exploring the effect of information technologies on teaching and learning among students and on society in general. Lately, He has been taking an interest in computer science teaching programs for young people.

Moanes H. TIBI

Computer Science Department, Faculty of Education

Address: Beit Berl College, 44905, Kfar Saba, Israel.

Phone: ++972522924110

E-mail: tibi@beitberl.ac.il; tibimoanes@gmail.com 


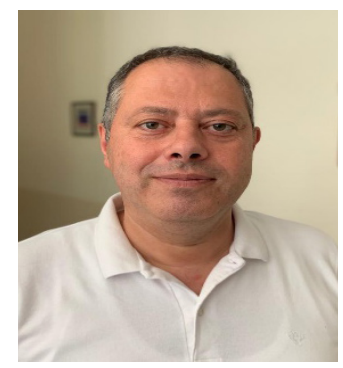

Dr. Arif ALTUN is a professor of computer education and instructional Technologies, and Director of Distance Education Center and the Informatics Institute at Hacettepe University, Ankara, Turkey. His current research areas include cognitiveemotional issues in learning with hypertext, designing personalized e-learning environments, computerized neuropsychological tests, and developing educational ontologies. He is currently running the ONTOLAB with a team of researchers to explore various cognitive and emotional processes in order to understand and develop sound instructional decisions for e-learning. Within the scope of this vision, he conducts and publishes research in learner profiling and ontology-based adaptive environments. Dr. Altun was the recipient of World Bank/Turkish Higher Educational Council scholarship to pursue his doctorate degree at the University of Cincinnati, and had visiting scholar positions at the University of Eau Claire (Pychology Department), and Harvard University Graduate School of Education (Mind, Brain, and Education Program).

\section{Arif ALTUN}

Hacettepe University, Faculty of Education

Department of Computer Education and Instructional Technologies

Address: Hacettepe University, 06800, Ankara, Turkey

Phone: +903122977176

E-mail: altunar@hacettepe.edu.tr

\section{REFERENCES}

Alshare, K. A., Freeze, R. D., Lane, P. L., \& Wen, H. J. (2011). The impacts of system and human factors on online learning systems use and learner satisfaction. Decision Sciences Journal of Innovative Education, 9(3), 437-461. doi: https://doi.org/10.1111/j.1540-4609.2011.00321.x

Alqurashi, E. (2016). Self-efficacy in online learning environments: A literature review. Contemporary Issues in Education Research, 9(1), 45. doi: https://doi.org/10.19030/cier.v9i1.9549

An, H., Kim, S., \& Kim, B. (2008). Teacher perspectives on online collaborative learning: Factors perceived as facilitating and impeding successful online group work. Contemporary Issues in Technology and Teacher Education, 8(1), 65-83.

Arbaugh,J.B.(2000).Virtualclassroom characteristicsand studentsatisfaction withInternet-based MBAcourses. Journal of Management Education, 24(1), 32. http://dx.doi.org/10.1177/105256290002400104

Bolliger, D.U. (2004). Key Factors for Determining Student Satisfaction in Online Courses. International Journal on E-Learning, 3(1), 61-67. Norfolk, VA: Association for the Advancement of Computing in Education (AACE). Retrieved March 7, 2019 from https://www.learntechlib.org/ primary $/ \mathrm{p} / 2226 /$.

Bolliger, D. U., \& Halupa, C. (2012). Student perceptions of satisfaction and anxiety in an online doctoral program. Distance Education, 33(1), 81-98. doi: https://doi.org/10.1080/01587919.2012.667961

Britto, M., \& Rush, S. (2013). Developing and implementing comprehensive student support services for online students. Journal of Asynchronous Learning Networks, 17, 29-42.

Chen, S. J. (2014). Instructional design strategies for intensive online courses: An objectivist-constructivist blended approach. Journal of Interactive Online Learning, 13(1), 72-86.

Chiu, C., M. Hsu, S. Sun, T. Lin, P. Sun, (2005), Usability, quality, value and e-learning continuance decisions. Computers \& Education, 45, 399-416. doi: https://doi.org/10.1016/j.compedu.2004.06.001

Cronbach, L. J., \& Meehl, P. E. (1955). Construct validity in psychological tests. Psychological Bulletin, 52(4), 174-203.

Croxton, R. A. (2014). The role of interactivity in student satisfaction and persistence in online learning. Journal of Online Learning and Teaching, 10(2), 314. 
McGorry, S. Y. (2003). Measuring quality in online programs. The Internet and Higher Education, 6(2), 159177. doi: https://doi.org/10.1016/S1096-7516(03)00022-8

Eom, S. B., \& Ashill, N. (2016). The determinants of students' perceived learning outcomes and satisfaction in university online education: An update. Decision Sciences Journal of Innovative Education, 14(2), 185-215. doi: https://doi.org/10.1111/dsji.12097

Eryilmaz, M. (2012). The effect of hyper media on academic achievement satisfaction and cognitive load of students by using adaptive presentation and adaptive navigation. (Unpublished doctoral dissertation). Ankara University:Ankara.

Fedynich, L., Bradley, K. S., \& Bradley, J. (2015). Graduate Students' Perceptions of Online Learning. Research in Higher Education Journal, 27, 1-13.

Fleiss, J. L. (1981). Balanced incomplete block designs for inter-rater reliability studies. Applied Psychological Measurement, 5(1), 105-112.

Fornell, C., \& Larcker, D. F. (1981). Evaluating structural equation models with unobservable variables and measurement errors. Journal of Marketing Research, 18, 39-50.

Gecer, A. K., \& Topal, A. D. (2015). Development of satisfaction scale for e-course: reliability and validity study. Journal of Theory \& Practice in Education (JTPE), 11(4), 1271-1287.

Gil, H. (2008). The challenge of the transition from online delivery to online teaching and learning. In K. McFerrin, R. Weber, R. Carlsen, D. A. Williset. (Eds.), Proceedings of Society for Information Technology and Teacher Education International Conference. Chesapeake, VA: AACE, 2589-2594.

Gonzalez-Gomez, F., Guardiola, J., Rodriguez, O. M., \& Alonso, M. A. M. (2012). Gender differences in e-learning satisfaction. Computers \& Education, 58(1), 283-290. doi: https://doi.org/10.1016/j. compedu.2011.08.017

Green, K. C. (2010). The Campus Computing Survey. Encino, CA: The Campus Computing Project. Retrieved from http://www.campuscomputing.net/2010-campus-computing-survey

Gunawardena, C. N., Linder-VanBerschot, J. A., LaPointe, D. K., \& Rao, L. (2010). Predictors of learner satisfaction and transfer of learning in a corporate online education program. The American Journal of Distance Education, 24(4), 207-226. doi: https://doi.org/10.1080/08923647.2010.522919

Gunawardena, C. N., \& Zittle, F. J. (1997). Social presence as a predictor of satisfaction within a computermediated conferencing environment. The American Journal of Distance Education, 11(3), 8-26.

Hair, J. F., Black, W. C., Babin, B. J., \& Anderson, R. E. (2009). Multivariate data analysis (7th Edition), Upper Saddle River, NJ [etc.]. Pearson Prentice Hall, New York, NY: Macmillan

Harsasi, M., \& Sutawijaya, A. (2018). Determinants of student satisfaction in online tutorial: A study of a distance education institution. Turkish Online Journal of Distance Education, 19(1), 89-99. doi: https://doi.org/10.17718/tojde.382732

Harvey, H. L., Parahoo, S., \& Santally, M. (2017). Should gender differences be considered when assessing student satisfaction in the online learning environment for millennials?. Higher Education Quarterly, 71(2), 141-158. doi: https://doi.org/10.1111/hequ.12116.

Hu, L., \& Bentler, P. M. (1995). Evaluating model fit. In R. H. Hoyle (Ed.), Structural equation modeling: Concepts, issues, and applications (p. 76-99). Sage Publications, Inc.

Hu, L., \& Bentler, P. M. (1999). Cutoff criteria for fit indexes in covariance structure analysis: Conventional criteria versus new alternatives. Structural Equation Modeling., 6, 1-55.

Hung M-L, Chou C, Chen C-H, \& Own, Z-Y. (2010) Learner readiness for online learning: Scale development and student perceptions. Computers \& Education, 55(3):1080-90. doi: https://doi. org/10.1016/j.compedu.2010.05.004

Ilgaz, H. (2008). The contribution of technology acceptance and community feeling to learner satisfaction in distance education [Uzaktan egitimde teknoloji kabulunun ve topluluk hissinin ogrenen memnuniyetine katkisi] (Unpublished master's thesis). Hacettepe University, Ankara. 
Jaggars, S. S., \& Xu, D. (2016). How do online course design features influence student performance?. Computers \& Education, 95, 270-284. doi: https://doi.org/10.1016/j.compedu.2016.01.014.

Kauffman, H. (2015). A review of predictive factors of student success in and satisfaction with online learning. Research in Learning Technology, 23, 1-13.

Kelecioglu, H., \& Sahin, S. G. (2014). Validity from Past to Present [Gecmisten gunumuze gecerlik]. Journal of Measurement and Evaluation in Education and Psychology, 5(2), 1-11. doi: https://doi. org/10.21031/epod.41706

Kirmizi, O. (2015). The influence of learner readiness on student satisfaction and academic achievement in an online program at higher education. Turkish Online Journal of Educational Technology-TOJET, 14(1), 133-142.

Kirtman, L. (2009). Online versus in-class courses: An examination of differences in learning outcomes. Issues in Teacher Education, 18(2), 103-116.

Kline, R. B. (2005). Principles and practice of structural equation modeling (2nd ed.). New York, NY: Guilford Press.

Kuo, Y. C., Walker, A. E., Belland, B. R., \& Schroder, K. E. (2013). A predictive study of student satisfaction in online education programs. The International Review of Research in Open and Distributed Learning, 14(1), 16-39. doi: https://doi.org/10.19173/irrodl.v14i1.1338

Kuo, Y. C., Walker, A. E., Schroder, K. E., \& Belland, B. R. (2014). Interaction, Internet self-efficacy, and self-regulated learning as predictors of student satisfaction in online education courses. The Internet and Higher Education, 20, 35-50. doi: https://doi.org/10.1016/j.iheduc.2013.10.001.

Kurucay, M., \& Inan, F. A. (2017). Examining the effects of learner-learner interactions on satisfaction and learning in an online undergraduate course. Computers \& Education, 115, 20-37.

Liaw, S. S., \& Huang, H. M. (2013). Perceived satisfaction, perceived usefulness and interactive learning environments as predictors to self-regulation in e-learning environments. Computers \& Education, 60(1), 14-24. doi: https://doi.org/10.1016/j.compedu.2012.07.015

Lim, C. K. (2001). Computer self-efficacy, academic self-concept, and other predictors of satisfaction and future participation of adult distance learners. The American Journal of Distance Education 15(2): 41-51. doi: https://doi.org/10.1080/08923640109527083

Lister, M. (2014). Trends in the design of e-learning and online learning. Journal of Online Learning and Teaching, 10(4), 671-680.

Martin-Rodriguez, O., Fernandez-Molina, J. C., Montero-Alonso, M. A., \& Gonzalez-Gomez, F. (2015). The main components of satisfaction with e-learning. Technology, Pedagogy and Education, 24(2), 267-277. doi: https://doi.org/10.1080/1475939X.2014.888370

McGorry, S. Y. (2003). Measuring quality in online programs. The Internet and Higher Education, 6(2), 159-177.

Milheim, K. L. (2012). Toward a better experience: Examining student needs in the online classroom through Maslow's hierarchy of needs model. Merlot Journal of Online Learning and Teaching, 8(2). Retrieved from http://jolt.merlot.org/

Nunnally, J. C., and I. H. Bernstein (1994). Psychometric Theory, 3rd ed. New York: McGraw-Hill.

Patil Vivek H, Surendra N. Singh, Sanjay Mishra, and D. Todd Donavan (2017). Parallel Analysis Engine to Aid in Determining Number of Factors to Retain using R [Computer software], available from https://analytics.gonzaga.edu/parallelengine/.

Parahoo, S. K., Santally, M. I., Rajabalee, Y., \& Harvey, H. L. (2016). Designing a predictive model of student satisfaction in online learning. Journal of Marketing for Higher Education, 26(1), 1-19. Doi: https://doi.org/10.1080/08841241.2015.1083511

Ralston-Berg, P., Buckenmeyer, J., Barczyk, C., \& Hixon, E. (2015). Students' perceptions of online course quality: How do they measure up to the research? Internet Learning Journal, 4(1), 38-55. 
Rios, T., Elliott, M., \& Mandernach, B. J. (2018). Efficient Instructional Strategies for Maximizing Online Student Satisfaction. Journal of Educators Online, 15(3).

Roper, A. R. (2007). How students develop online learning skills. Educause Quarterly, 30(1), 62-65.

Sahin, I., \& Shelley, M. (2008). Considering students' perceptions: the distance education student satisfaction model. Journal of Educational Technology \& Society, 11(3).

Sebastianelli, R., Swift, C., \& Tamimi, N. (2015). Factors affecting perceived learning, satisfaction, and quality in the online MBA: A structural equation modeling approach. Journal of Education for Business, 90(6), 296-305. Doi: https://doi.org/10.1080/08832323.2015.1038979

Tibi, M. H. (2015). Improving collaborative skills by computer science students through structured discussion forums. Journal of Technologies in Education, 10 (3-4), 27-41. doi:10.24059/olj.v22i1.995

Turhangil Erenler, H. H. (2019). A structural equation model to evaluate students' learning and satisfaction. Computer Applications in Engineering Education. https://doi.org/10.1002/cae.22189

Uusiautti, S., Maatta, K., \& Leskisenoja, E. (2017). Succeeding Alone and Together-University Students' Perceptions of Caring Online Teaching. Journal of Studies in Education, 7(2), 48-66. doi: https:// doi.org/10.5296/jse.v7i2.11162

Wallace, R. M. (2003). Online learning in higher education: A review of research on interactions among teachers and students. Education, Communication, and Information, 3(2), 241-280. doi: https:// doi.org/10.1080/14636310303143

Ward, M., Peters, G., \& Shelley, K. (2010). Student and faculty perceptions of the quality of online learning experiences. The International Review of Research in Open and Distributed Learning, 11(3), 57-77. doi:http://dx.doi.org/10.19173/irrodl.v1 1i3.867

Williams, B., Onsman, A., \& Brown, T. (2010). Exploratory factor analysis: A five-step guide for novices. Australasian Journal of Paramedicine, 8(3).

Young, A., \& Norgard, C. (2006). Assessing the quality of online courses from the students' perspective. The Internet and Higher Education, 9(2), 107-115. doi: https://doi.org/10.1016/j.iheduc.2006.03.001

Yurdugul, H., \& Alsancak Sirakaya, D. (2013). The scale of online learning readiness: A study of validity and reliability. Education and Science, 38, 391-406.

Yurdugul, H., \& Bayrak, F. (2012). Content validity criteria in scale development studies: Comparison of content validity index and Kappa statistics [Olcek Gelistirme Calismalarinda Kapsam Gecerlik Olculeri: Kapsam Gecerlik Indeksi ve Kappa Istatistiginin Karsilastirilmasi]. Hacettepe University Journal of Education, 2(Special Issue), 264-271

Yukselturk, E., \& Yildirim, Z. (2008). Investigation of interaction, online support, course structure and flexibility as the contributing factors to students' satisfaction in an online certificate program. Educational Technology \& Society, 11(4), 51-65. 
APPENDIX

\section{ORLS Dimensions and Items}

\begin{tabular}{|c|c|c|}
\hline & Turkish & English \\
\hline Item 1 & $\begin{array}{l}\text { Donem boyunca ogretmenlerimle etkili bicimde } \\
\text { iletisim halinde bulunmaktan memnunum. }\end{array}$ & $\begin{array}{l}\text { I am satisfied to communicate effectively with my } \\
\text { teachers throughout the semester. }\end{array}$ \\
\hline Item 2 & $\begin{array}{l}\text { Ogretmenlerimin derse iliskin cesitli egitsel } \\
\text { materyallere ulasabilmem konusunda desteginden } \\
\text { memnunum. }\end{array}$ & $\begin{array}{l}\text { I am satisfied with the support of my teachers in } \\
\text { accessing various educational materials related to } \\
\text { the course. }\end{array}$ \\
\hline Item 3 & $\begin{array}{l}\text { Ogretmenlerimin cevrimici ogrenme konusunda } \\
\text { hevesli olmasindan memnunum. }\end{array}$ & $\begin{array}{l}\text { I am satisfied that my teachers are enthusiastic } \\
\text { about online learning. }\end{array}$ \\
\hline Item 4 & $\begin{array}{l}\text { Cevrimici ortamda ogretmenlerimden geribildirim } \\
\text { alabilmekten memnunum. }\end{array}$ & $\begin{array}{l}\text { I am satisfied to receive feedback from my teachers } \\
\text { online }\end{array}$ \\
\hline Item $5^{*}$ & $\begin{array}{l}\text { Unitelerin belirli bir plan dahilinde acilmasindan } \\
\text { memnunum. }\end{array}$ & $\begin{array}{l}\text { I am satisfied that the units have been set up on a } \\
\text { specific schedule. }\end{array}$ \\
\hline Item 6 & $\begin{array}{l}\text { Unitelerin sunum sekillerinin tutarli olmasindan } \\
\text { memnunum. }\end{array}$ & $\begin{array}{l}\text { I am satisfied that the presentation of the units is } \\
\text { consistent. }\end{array}$ \\
\hline Item 7 & $\begin{array}{l}\text { Icerigin sunumunda kullanilan dilin acik ve anlasilir } \\
\text { olmasindan memnunum. }\end{array}$ & $\begin{array}{l}\text { I am satisfied that the language used in the } \\
\text { presentation of the content is clear and } \\
\text { understandable. }\end{array}$ \\
\hline Item $8^{*}$ & Cevrimici sistemin hizindan memnunum. & I am satisfied with the speed of the online system. \\
\hline Item 9 & $\begin{array}{l}\text { Cevrimici sistemin kullaniminin kolay olmasindan } \\
\text { memnunum. }\end{array}$ & I am satisfied that the online system is easy to use. \\
\hline Item 10 & $\begin{array}{l}\text { Cevrimici ogrenme ortaminda gereksinimlerimin } \\
\text { karsilanmasindan dolayi memnunum. }\end{array}$ & $\begin{array}{l}\text { I am satisfied that my needs are met in the online } \\
\text { learning environment. }\end{array}$ \\
\hline
\end{tabular}

